\title{
Influence of a Kefir-Derived Antimicrobial Fraction on Zika Virus Cytopathic Effects and Lymphocyte Proliferation
}

Gabrielle Ribeiro de Andrade ${ }^{1}$, Irys Viana Neves², Vaniky Duarte Marques ${ }^{2}$, Monamaris Marques Borges ${ }^{2}$, Tiago Antonio Martinhago Broring ${ }^{3}$, Marina Tavares dos Anjos ${ }^{4}$, Renato Mancini Astray ${ }^{5}$ and Marta de 0 liveira Domingos $^{2 *}$

${ }^{1}$ Special Laboratory for Zoological Collections, Instituto Butantan, São Paulo, Brazil.

${ }^{2}$ Laboratory of Bacteriology, Instituto Butantan, São Paulo, Brazil.

${ }^{3}$ present address: Werfen: Diagnostic Solutions for life, Barueri, São Paulo, Brazil

${ }^{4}$ present address: AVISA, Technical services for sanitary vigillance, technology and environment, Ltd EPP, São Paulo, Brazil

${ }^{5}$ Laboratory of Immunovirology, Instituto Butantan, São Paulo, Brazil.

Submission: June 16, 2017; Published: July 07, 2017

*Corresponding authors: Marta de Oliveira Domingos, Laboratory of Bacteriology, Instituto Butantan, Avenida Vita Brasil, 1500, CEP 05503000, São Paulo, Brazil, Tel: 5511 26279708; Email: marta.domingos@butantan.gov.br

\begin{abstract}
Several studies have already demonstrated the ability of probiotics to fight virus infection either by enhancing the host immune response or by inhibiting viral adhesion to the host cells. The aim of this work was to determine the ability of an antimicrobial fraction derived from kefir to inhibit the cytopathic effect of Zika virus on epithelial cells. In addition, the influence of this fraction on lymphocytes was also investigated. The results demonstrated that after $72 \mathrm{~h}$ of infection the antimicrobial fraction, at a concentration of $37.5 \mu \mathrm{g} / \mathrm{mL}$, was able to inhibit $44 \%$ of Zika virus cytopathic effect on Vero cells. The results also showed a decrease in the humoral immune response of mice immunized subcutaneously with BSA adsorbed on alum in the presence of the antimicrobial fraction. However, the number of B and T lymphocytes in their spleen was not affected. In contrast, the proliferative effect of Concanavalin A (ConA) on T cells was fully inhibited by the fraction. In summary, the results suggest that the antimicrobial fraction derived from kefir has an anti-virus effect that can be improved either by exploiting its ability to reduce viral cytopathic effect or by antagonizing the influence that some types of viruses have on T-lymphocyte proliferation.
\end{abstract}

Keywords: Zika virus; Kefir antimicrobial fraction; T cells; ConA

\section{Introduction}

A huge increase in the number of new emerging viral diseases such as dengue, Chikungunya, Ebola and lately Zika, a flavivirus transmitted by Aedes mosquitos, has become a serious problem in public health worldwide [1], especially taking into consideration the fact that there are not enough drugs in the pharmaceutical pipeline to control the evolution of viral drugresistance. For these reasons, there is a continual search for new antiviral agents to replace the current ones used in the medical practice when they become ineffective. In the search for anti-viral drugs with few side effects, several studies have investigated whether probiotic products could be utilized as remedies against viral diseases. The results obtained by these studies have demonstrated that probiotic products have the potential to be used as medicines against viral infection [2-4]. In this regard, a very interesting study was published by Morsy and colleagues [5], who demonstrated that patients with chronic hepatitis $\mathrm{C}$ virus infection could benefit by drinking kefir. Our results also indicate that kefir has anti-viral properties since we have shown that a molecular fraction with mass lower than $3 \mathrm{kDa}$ derived from milk kefir was able to inhibit the cytopathic effect of Zika virus on Vero cells. In this experiment, the cytopathic effect 
of Zika virus was observed after 72 hours incubation of cells in 96 well cell culture plates containing $5 \times 10^{4}$ cells $/ \mathrm{mL}(100 \mu \mathrm{l} /$ well) of fresh VP SFM medium [6] diluted serially with kefir antimicrobial fraction at the following concentrations: $150 \mu \mathrm{g} /$ $\mathrm{mL}$ to $0.29 \mu \mathrm{g} / \mathrm{mL}$. After 2 hours incubation, a MOI (multiplicity of infection) of 0.1 plaque-forming unit/cell of Zika virus culture was added to the wells at a final volume of $100 \mu \mathrm{g}$ per/well. After $72 \mathrm{~h}$ of incubation, the plates were stained and read, revealing a $44 \%$ CPE (cytopathic effect) inhibition when the antimicrobial fraction of Kefir was used at $37.5 \mu \mathrm{g} / \mathrm{mL}$ (Figure 1).
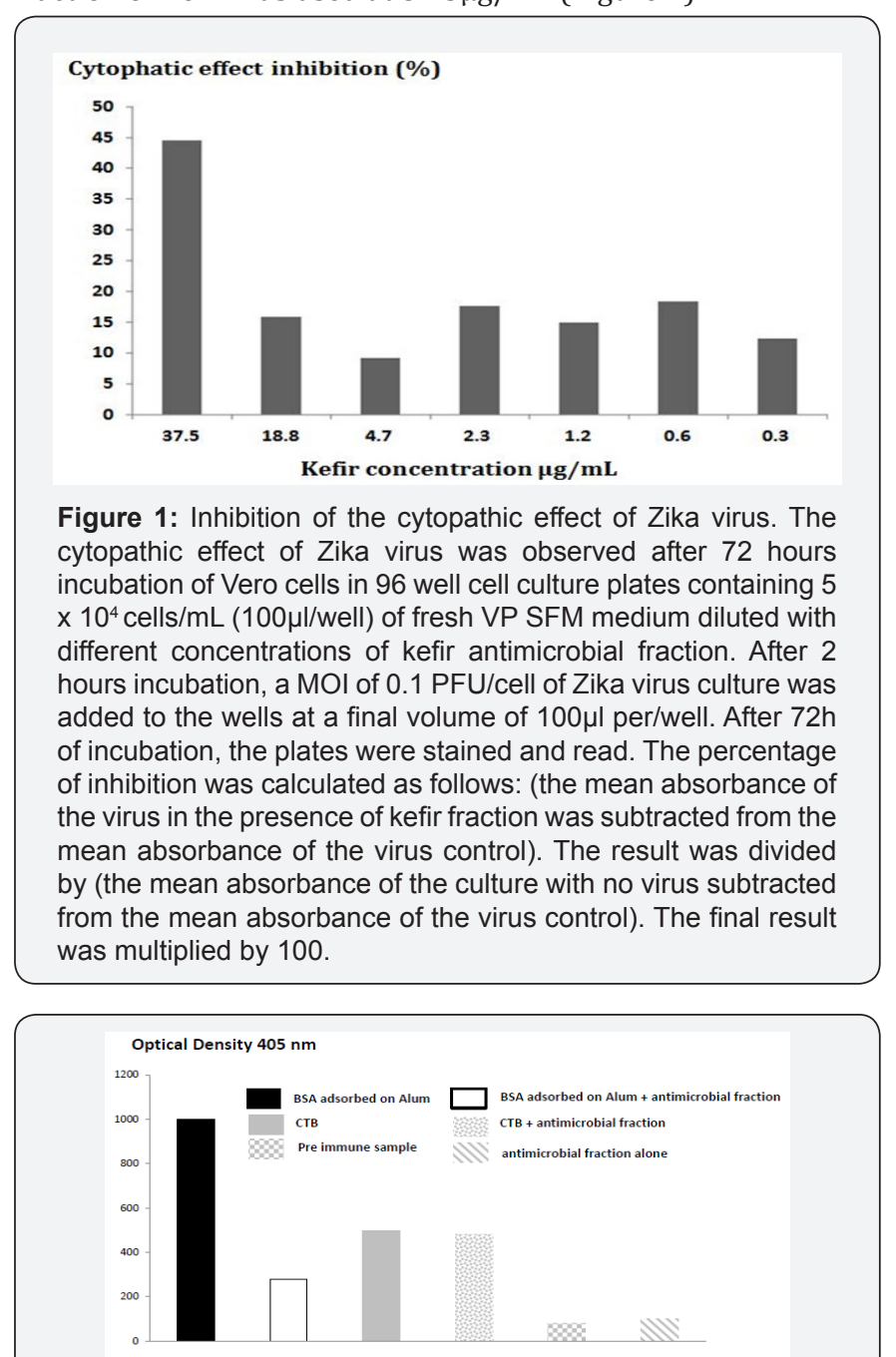

Figure 2: Influence of the antimicrobial fraction on the humoral response against CTB and BSA. Balb/c female mice were immunized subcutaneously twice either with CTB or BSA adsorbed on alum (with or without the antimicrobial fraction). Seven days after the last immunization blood samples were collected, pooled, diluted $1 / 720$ and the IgG response against CTB and BSA was determined by ELISA. This experiment was repeated twice with similar results.

Other studies have also demonstrated that kefir metabolites are able to arrest proliferation and induce apoptosis of HTLV1 negative malignant lymphocytes [7]. Likewise, studies using probiotic bacteria instead of metabolites have demonstrated that the probiotic bacteria themselves can help the immune system to fight viral infection by enhancing the host's immune response. A good example is the work of Sugimura and colleagues who demonstrated that Lactococcus lactis JCM5808 activates plasmocytoid dendritic cells in vivo and increases their ability to produce IFNs (interferons) [8]. In addition, Yang and coworkers [9] have demonstrated that oral immunization of chickens with a recombinant probiotic L. plantarum expressing NP-M1DCpep from H9N2 avian influenza virus (AIV) significantly increased T-cell-mediated immune responses, mucosal $\operatorname{sig} \mathrm{A}$ and IgG levels, and provided protection against H9N2 AIV challenge. Accordingly, it was decided in the present work to determine whether the humoral immune response induced by CTB (the B subunit of Cholera Toxin), a very potent immune adjuvant would be influenced by co-administration with the antimicrobial fraction of kefir. The results demonstrated that the humoral immune response against CTB of mice immunized subcutaneously with $1 \mu \mathrm{g} / \mathrm{mL}$ of CTB $(100 \mu \mathrm{l} /$ animal) in PBS diluted (1/2) with the antimicrobial fraction was equivalent to the response generated by the group immunized with $1 \mu \mathrm{g} / \mathrm{mL}$ of CTB in PBS, showing that in this case the kefir fraction did not enhance the immune response generated by CTB (Figure 2). In order to determine whether the fraction would interfere with the humoral response generated in the presence of another adjuvant such as alum, female Balb/c mice (6 to 8 weeks old) were immunized subcutaneously twice with BSA adsorbed on alum in the presence or absence of the antimicrobial fraction. Seven days after the last immunization blood was collected, pooled and the IgG response against BSA was measured. Contrary to what was observed previously with CTB, the IgG response against BSA generated by the group immunized with BSA on alum in the presence of the fraction was much lower than the response obtained by the group control immunized with BSA on alum in PBS (Figure 2). These data indicate that depending on the antigen and the adjuvant used for immunization, the antimicrobial fraction can influence the immune response in different ways. Therefore, in this study, the influence of the antimicrobial fraction of kefir on the proliferation of T and B cells in-vivo was examined. For this experiment, seven days after the last immunization, the splenic cells of the animals immunized subcutaneously with BSA adsorbed onto alum in the presence or absence of the antimicrobial fraction were incubated for 30 minutes with the following antibodies: rat IgG anti-mouse CD3Tricolor, rat IgG anti-mouse CD4 labelled with FITC, rat IgG anti mouse CD8 labelled with (PE) and rat IgG anti mouse CD 45R labelled with PE. After 30 minutes of incubation with the afore-mentioned antibodies, the lymphocyte population profiles were determined by FACS according to the manufacturer's instructions. The results obtained in these experiments showed that the number of $\mathrm{B}$ and $\mathrm{T}$ cells of mice immunized with BSA adsorbed onto alum in the presence of the antimicrobial fraction was equivalent to the number encountered in the group of mice immunized with BSA on alum in PBS (Figure 3). In addition, the number of T cells (CD4 and CD8) was not altered 
by co-immunization with the antimicrobial fraction (Figure 4). Nevertheless, some studies have shown that kefir can influence the number of malignant $\mathrm{T}$ cells [7]. Therefore, it was decided to determine the influence of the kefir antimicrobial fraction on $\mathrm{T}$ cell proliferation induced by ConA. For this experiment, seven days after the last immunization, the splenic cells of the animals immunized subcutaneously with BSA adsorbed onto alum in the presence or absence of the antimicrobial fraction were incubated with ConA in RPMI-1640 medium either alone or in the presence of the antimicrobial fraction diluted two-fold in RPMI-1640 medium (Sigma). The incubation was performed for $72 \mathrm{~h}$ at 37 ${ }^{\circ} \mathrm{C}$ in a $5 \%$ carbon dioxide atmosphere. After incubation, the ability of ConA to induce $\mathrm{T}$ cell proliferation was determined by the MTT methodology [10]. The results demonstrated that the kefir antimicrobial fraction was able to inhibit fully the proliferative effect of ConA on T cells (Figure 5), indicating that this fraction has the potential to inhibit proliferation of malignant T lymphocytes, as previously demonstrated by Maalouf and coworkers [7].

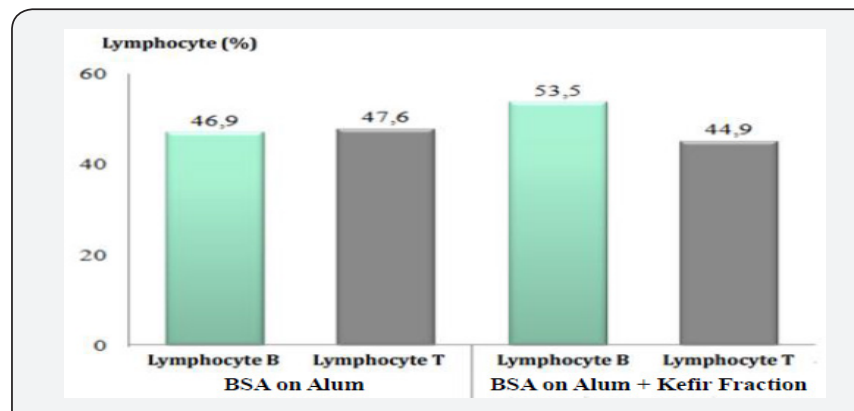

Figure 3: Influence of the antimicrobial fraction on B and T cells. Spleens of mice immunized with BSA on alum (with or without the fraction) were collected 7 days after the last immunization and their cells were incubated with the following conjugates labeled with florescent markers: rat IgG anti-mouse CD3 and rat $\lg$ anti mouse CD45R. After incubation, the percentage of $B$ and $T$ cells was determined by FACS. This experiment was repeated twice with similar results.

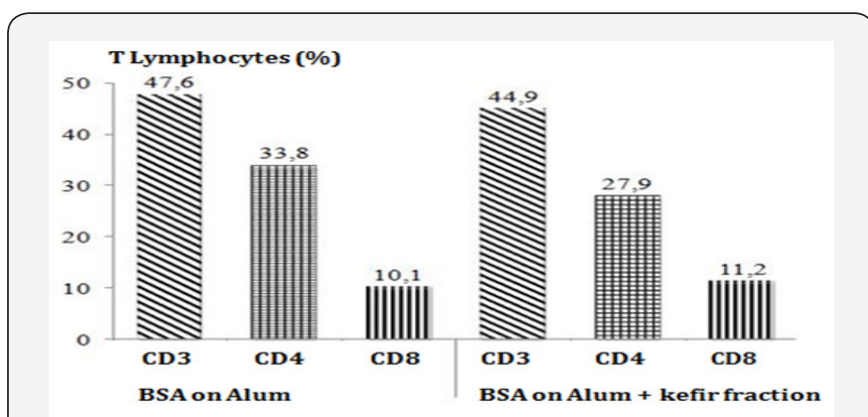

Figure 4: Influence of the antimicrobial fraction on CD4 and CD8 T cell populations. Spleens of mice immunized with BSA on alum were collected 7 days after the last immunization and their cells were incubated with the following conjugates labeled with florescent markers: rat $\lg G$ anti-mouse $C D 3$, rat $\lg G$ antimouse CD4 and rat IgG anti-mouse CD8. After incubation, the percentage of CD4 and CD8 T cells was determined by FACS. This experiment was repeated twice with similar results.

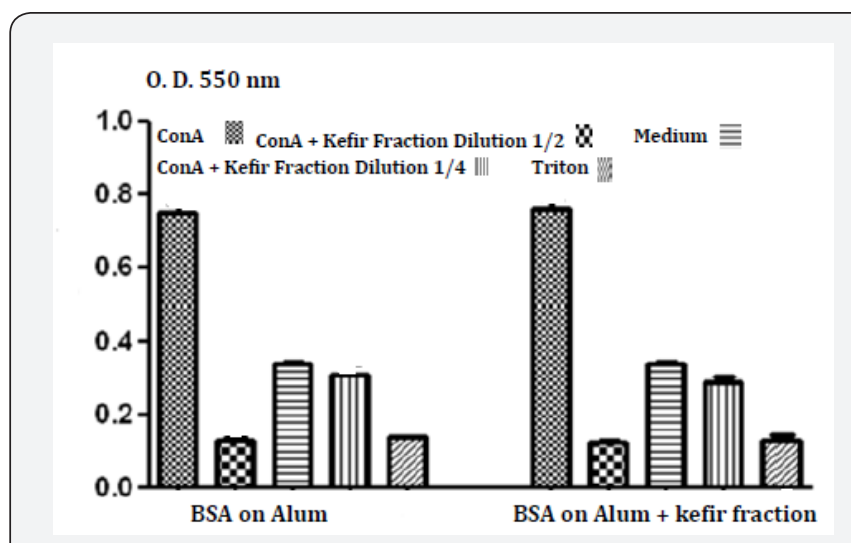

Figure 5: Influence of the kefir antimicrobial fraction on $\mathrm{T}$ cell proliferation induced by ConA. The splenic cells of animals immunized subcutaneously with BSA adsorbed onto alum (in the presence or absence of the antimicrobial fraction) were incubated in vitro with ConA in RPMI-1640 medium (with or without the antimicrobial fraction). The incubation was performed for $72 \mathrm{~h}$ at $37^{\circ} \mathrm{C}$ in a $5 \%$ carbon dioxide atmosphere. Subsequently, the ability of ConA to induce $\mathrm{T}$ cell proliferation was determined by the MTT methodology. This experiment was repeated twice with similar results.

\section{Conclusion}

The results obtained in the present work suggest that the antimicrobial fraction isolated from kefir has the potential to be used as an antiviral medicine. However, in order to be used as a product, the fraction needs to be better characterized and its mechanism of action has to be elucidated further.

\section{Acknowledgement}

The authors would like to thank Dr. Roger R C New for correcting the English of the manuscript.

\section{References}

1. Saiz JC, Vazquez-Calvo A, Blázquez AB, Merino-Ramos T, EscribanoRomero E, et al. (2016) Zika Virus: the Latest Newcomer. Front Microbiol 7: 496.

2. Olaya Galán NN, Ulloa Rubiano JC, Velez Reyes FA, Fernandez Duarte KP, Salas Cárdenas SP, et al. (2016) In-vitro antiviral activity of Lactobacillus casei and Bifidobacterium adolescentis against rotavirus infection monitored by NSP4 protein production. J Appl Microbiol $120(4): 1041-1051$.

3. Fernandez-Duarte KP, Olaya-Galán NN, Salas-Cárdenas SP, LopezRozo J, Gutierrez-Fernandez MF (2017) Bifidobacterium adolescentis (DSM 20083) and Lactobacilus casei (Lafti L26-DSL) Probiotics able to Block the in vitro adherence of Rotavirus in MA104 cells. Probiotics Antimicrob Proteins.

4. Starosila D, Rybalko S, Varbanetz L, Ivanskaya N, Sorokulova I (2017) Anti-influenza activity of Bacillus subtilis probiotic strain. Antimicrob Agents Chemother 61(7): e00539-17.

5. Morsy RM Mahmoud AM, Zanaty MI, Abdel-Moneim A, Abo-Self MA (2014) Beneficial Effects of Milk Kefir in Patients with Chronic Hepatitis C Virus-Infection. International Hournal of Bioassays 3(6): 3086-3091.

6. Frazzati-Gallina NM, Paoli RL, Mourão-Fuches RM, Jorge SA, Pereira CA (2001) Higher production of rabies vírus in serum-free medium cell cultures on microcarriers. J Biotechnol 92(1):67-72. 
7. Maalouf K, Baydon E, Rizk S (2011) Kefir induces cell-cycle arrest and apoptosis in HTLV-I-negative malignant T-lymphocytes. Cancer Manag Res 14(3): 39-47.

8. Sugimura T, Jounai K, Ohshio K, Tanaka T, Suwia M, et al. (2013) Immunomodulatory effect of Lactococcus lactis JCM5805 on human plasmacytoid dendritic cells. Clin Immunol 149(3): 509-518.

9. Yang WT, Yang GL, Shi SH, Liu YY, Huang HB, et al. (2017) Protection of chickens against H9N2 avian influenza virus challenge with recombinant Lactobacillus planetarium expressing conserved antigens. Applied Microbiol. Appl Microbiol Biotechnol 101(11): 45934603.

10. Mosmann T (1983) Rapid colorimetric assay for cellular growth and survival: application to proliferation and cytotoxicity assays. J Immunol Methods 65(1-2): 55-63.

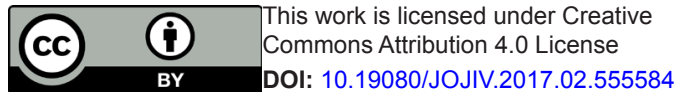

\begin{tabular}{l} 
Your next submission with Juniper Publishers \\
will reach you the below assets \\
- Quality Editorial service \\
- Swift Peer Review \\
- Reprints availability \\
- E-prints Service \\
- Manuscript Podcast for convenient understanding \\
- Global attainment for your research \\
- Manuscript accessibility in different formats \\
( Pdf, E-pub, Full Text, Audio) \\
- Unceasing customer service \\
Track the below URL for one-step submission \\
https://juniperpublishers.com/online-submission.php \\
\hline
\end{tabular}

